座 長 集 約

\section{レーザイメージャ用フイルム（演題番号 1～5）}

段床嘉晴（大阪大学医学部附属病院）

CT. MRI の画像記録にレーザイメージャの導入が進 み，専用フィルムの使用が増えてきている．医用画像機 器の進歩にともなって, 取り扱うフィルムはX線フィル ムの他にCRT 用, レーザ用, サブトラクション用, デュ 一プ用など種類が多様化してきている。また現像機も処 理速度の向上が進み，多様なフィルムとの適合性にも留 意しなければならない.レーザイメージャ用フィルムの 特性の把握，センシトメトリの方法などが使用上欠かせ ないテーマとなっている.今回の演題区分ではレーザ用 フィルムの他に CRT 用フィルム, CRT 診断の画像評価 が 1 題ずつ含まれている.

演題 1 はレーザイメージャ用フィルムのプリンタとの 適合性を検討し，問題のないことを報告している．特性 の似た 2 種類のフィルムの比較であるが, 特性の異なる フィルムの場合プリンタのキャリブレーションシステム が有効となることは後の演題 4 でも報告されている.

演題 2 は高速処理が可能な CRT 用フィルムの開発に 関する報告で, 薄層化, 粒子細密充填, 分光増感といっ た開発技術によって感度, 鮮鋭度, 処理特性, 沉用性の 向上が計られたということであるが，各種マルチフォー マットカメラや自動現像機との適合性を考慮している.

僙問（柴田 福岡新小倉病院） 高速処理にとって定 着速度の向上が必要条件であるが，沃化銀の低下の割合 はどれくらいか.

答 $\mathrm{m}^{2}$ 当たりのヨード量として従来より $30 \%$ 位まで 隇らしている。

演題 3 は45秒処理が可能なレーザイメージャ用フィル 厶の開発経過の報告でCRTフィルムと同様に多くの機

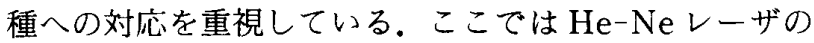
波長に合わせた新しい分光増感色素と増感色素吸着技術 の開発を中心に高感度，高速処理を可能にしている.

質問（大下 宮城）特性曲線を作成する際に使用し ている光源はどんなものを使用しているか. また, $\mathrm{He}^{-}$ $\mathrm{Ne}$ と半導体レーザの光源の場合でコントラストが異な っているが，何故そうなったのか.

答 センシトメトリの光源はスキャナ光源の $\mathrm{He}^{-} \mathrm{Ne}$ レーザを使って行っている.また, $\mathrm{He}-\mathrm{Ne}$ と半導体の広
範な機種に対応できるように，それぞれに合ったコント ラストということで変えている。フィルムの色素が現像 液を污染する恐れはないかとの質問に対して，その点は 充分考慮しており現像液中で消色，脱色するような化合 物を使用しているとのことであった。

演題 4 は異なった特性を持つイメージングフィルムに 対してレーザイメージャが装備しているルックアップテ ーブルにより出力画像特性の最適化をはかったという報 告である. 演題 1 のキャリブレーションシステムやこの 演題のルックアップテーブルは詠断する時の好みに合っ た画像特性を作るため，あるいは経年変化の補正に利用 するシステムであり，その利用法を熟知することは使用 者として当然のことであるが，将来複数のモダリティを 接続して利用するときの対応はどのようになるのであろ うか.

䍃問（市川 名市大） 最適なルックアップテーブル という定義はどこにあるのか.

答 写真を見て, 平均して一番良いと思われるところ を最適と決めた。観察モニタとの対比はしていない.

演題 5 はレーザによるフィルムデジタイザを利用して CRT 表示をしたときの検出能の評価をしている. CRT 診断の可能性をCRTのマトリックスサイズとの関連で 検討しているが，フィルム画像にかわるCRT 診断には 高精細 CRT が必要であることを示唆している.

質問（小水 滋賀医大）拡大表示をしていたが，ど ういう拡大をしたのか.

答 補間はしていない，等質拡大である。

「画像記録装置」（演題番号 6 ～12）

$$
\text { 三塩宏二（埼玉県立がんセンター） }
$$

このセッションでは，レーザイメージャに関する演題 が 5 題, CRT イメージャに関する演題が 2 題の計 7 演題 の発表が行われた．以下に演題ごとに質疑討論を含めて まとめる。

演題 6 は，コニカ社製レーザイメージャに関する性能 評価を従来の CRTイメージャと対比させながら行い両 者の画質の違いを客観的な数値データとして報告した。 これによると, 特に濃度の均一性, 解像度において CRT イメージャよりすぐれているとのことであった。

筫問（中川 聖マリアンナ医大） あるレーザイメー 